\title{
AUDIT MANAJEMEN ATAS FUNGSI SUMBER DAYA MANUSIA PADA PT. TASPEN (PERSERO) KCU SEMARANG
}

\author{
Etik Nur Aini Romdhoniyati ${ }^{1}$ \\ Jurusan Akuntansi, Politeknik Negeri Semarang, Semarang, \\ Indonesia, etiknur27@gmail.com \\ Heni Widyarti 2 \\ Jurusan Akuntansi, Politeknik Negeri Semarang, Semarang \\ Indonesia, heniwidyarti67@gmail.com \\ Ardian Widiarto ${ }^{3}$ \\ Jurusan Akuntansi, Politeknik Negeri Semarang, Semarang \\ Indonesia, ardian.widiarto@polines.ac.id
}

\begin{abstract}
ABTRACT
Background - Improve the quality and convenience of customers in social insurance services. PT. Taspen (Persero) KCU Semarang requires a management audit to evaluate and provide recommendations that need to be done to obtain effective human resources. interview with the Head of General and HR Section and several employees at PT. Taspen (Persero) KCU Semarang, the function of human resources (HR) at PT. Taspen (Persero) KCU Semarang can be said to have not been effective.
\end{abstract}

Purpose - The purpose of this study was to determine the implementation of the eight Human Resource functions and the effectiveness of the Human Resource function at PT. Taspen (Persero) KCU Semarang.

Design/ Methodology/ Approach - This research used descriptive qualitative. Data were collected using interview methods, questionnaires, and documentation studies. Data analysis used management audit with four stages, namely preliminary audits, review and testing of management controls, detailed audits, and reports.

Result and discussion - Five of the eight HR functions at PT. Taspen (Persero) KCU Semarang has been implemented effectively, namely (1) performance appraisal, (2) career development, (3) reward and compensation system, (4) employee protection and (5) employment relations. Meanwhile, the three functions that have not been implemented effectively include (1) orientation and placement, (2) training and development, and (3) termination of employment.

Conclusion - The eight management functions have not fully achieved the expected effectiveness in accordance with the audit indicators in the human resources function.

Research Implication - The implications in research for PT Taspen (Persero) KCU Semarang can be used as material for consideration and evaluation of three HR functions that have not been implemented effectively, so that they can be used for decision making to improve HR management performance, especially in the general section.

Keywords : Management, Audit, HR function, effectiveness

\section{ABSTRAK}

Latar Belakang - Meningkatkan kualitas dan kenyamanan nasabah dalam pelayanan asuransi sosial. PT. Taspen (Persero) KCU Semarang membutuhkan audit manajemen untuk mengevaluasi dan memberikan rekomendasi yang perlu dilakukan untuk mendapatkan sumber daya manusia yang efektif. wawancara dengan Kepala Bagian Umum dan SDM serta beberapa karyawan di PT. Taspen (Persero) KCU Semarang, Fungsi Sumber Daya Manusia (SDM) pada PT. Taspen (Persero) KCU Semarang bisa dikatakan belum efektif

Tujuan - Tujuan penelitian ini adalah mengetahui pelaksanaan delapan fungsi SDM dan efektivitas fungsi SDM pada PT. Taspen (Persero) KCU Semarang. 
Desain/metodologi/pendekatan - Penelitian ini bersifat deskriptif kualitatif. Data dikumpulkan menggunakan metode wawancara, kuesioner, dan studi dokumentasi. Analisis data menggunakan audit manajemen dengan empat tahapan yaitu audit pendahuluan, review dan pengujian pengendalian manajemen, audit terinci, dan laporan.

Hasil dan pembahasan - Lima dari delapan fungsi SDM pada PT. Taspen (Persero) KCU Semarang telah dilaksanakan dengan efektif, yakni (1) penilaian kinerja, (2) pengembangan karier, (3) sistem imbalan dan kompensasi, (4) perlindungan karyawan dan (5) hubungan ketenagakerjaan. Sementara tiga fungsi yang belum dilaksanakan dengan efektif antara lain (1) orientasi dan penempatan, (2) pelatihan dan pengembangan, dan (3) pemutusan hubungan kerja.

Kesimpulan - Delapan fungsi manajemen belum sepenuhnya memiliki efektivitas yang diharapkan sesuai dengan indikator audit di fungsi sumber daya manusia.

Implikasi Penelitian - Implikasi dalam penelitian bagi PT.Taspen (Persero) KCU Semarang dapat digunakan sebagai bahan pertimbangan dan evaluasi mengenai tiga fungsi SDM yang belum dilaksanakan secara efektif, sehingga dapat digunakan untuk pengambilan keputusan untuk memperbaiki kinerja manajemen SDM khususnya pada bagian umum.

Kata Kunci: Audit Manajemen, fungsi SDM, efektivitas

\section{PENDAHULUAN}

Saat ini di Indonesia sedang mengalami gejolak ekonomi yang mengakibatkan pertumbuhan ekonomi melemah dan daya beli masyarakat yang semakin menurun. Masalah ekonomi tersebut tidak hanya membawa dampak pada perusahaan manufaktur, tetapi juga berpengaruh terhadap perkembangan bisnis di bidang keuangan khususnya jasa asuransi. Menurut Undang-Undang No 40 Tahun 2014 tentang Perasuransian, Asuransi adalah perjanjian antara dua pihak, pihak yang satu berkewajiban membayar iuran dan pihak yang lain berkewajiban memberikan jaminan sepenuhnya kepada pembayar iuran apabila terjadi sesuatu yang menimpa pihak pertama atau barang miliknya sesuai dengan perjanjian yang dibuat. Selain memberikan jaminan kepada pihak pembayar iuran, perusahaan asuransi juga bertujuan untuk mencapai keuntungan, mempertahankan kelangsungan hidup, mengejar pertumbuhan dan menampung tenaga kerja.

Menurut Rosuliana et al., 2017 Tenaga Kerja atau Sumber Daya Manusia (SDM) merupakan aset potensial yang dimiliki organisasi dan berperan penting dalam pencapaian tujuan organisasi. Sebagus apapun tujuan, visi, misi, dan strategi organisasi tidak akan berguna apabila sumber daya manusianya tidak diperhatikan dan dikelola dengan baik (Anawati, 2016). Hakim (2014) menyatakan bahwa pengelolaan SDM di dalam organisasi inilah yang dikenal sebagai manajemen SDM. Menurut Hasibuan (2017) Manajemen SDM adalah ilmu dan seni mengatur hubungan dan peranan tenaga kerja agar efektif dan efisien membantu terwujudnya tujuan perusahaan, karyawan dan masyarakat. 
Menurut Nur dan Siregar (2019) Manajemen memerlukan suatu alat penilaian kinerja untuk menilai apakah program-program dan aktivitas-aktivitas pada fungsi SDM sudah sesuai dengan upaya dalam pencapaian tujuan perusahaan. Jenis evaluasi yang umumnya dilakukan yaitu evaluasi manajemen atau audit manajemen. Menurut Bayangkara (2017) Audit manajemen menekankan penilaian (evaluasi) terhadap berbagai aktivitas sumber daya manusia yang terjadi pada perusahaan dalam rangka memastikan apakah aktivitas tersebut telah berjalan secara ekonomis, efisien, dan efektif dalam mencapai tujuannya dan memberikan rekomendasi perbaikan atas berbagai kekurangan yang masih terjadi pada aktivitas sumber daya manusia yang diaudit untuk meningkatkan kinerja dari program atau aktivitas tersebut.

Pada penelitian ini, audit manajemen akan memfokuskan pada aktivitas pengendalian terhadap fungsi sumber daya manusia di PT. Taspen (Persero) KCU Semarang. PT. Taspen (Persero) KCU Semarang merupakan perusahaan yang bergerak di bidang asuransi sosial, yang di dalam organisasinya memerlukan sumber daya manusia yang berkualitas dan professional di bidangnya. Hal ini ditujukan untuk meningkatkan mutu dan kenyamanan nasabah dalam pelayanan asuransi sosial. PT. Taspen (Persero) KCU Semarang memerlukan audit manajemen untuk mengevaluasi dan memberikan rekomendasi yang perlu dilakukan untuk mendapatkan SDM yang efektif.

Berdasarkan hasil wawancara dengan Kepala Seksi Umum dan SDM dan beberapa karyawan di PT. Taspen (Persero) KCU Semarang, fungsi sumber daya manusia (SDM) pada PT. Taspen (Persero) KCU Semarang dapat dikatakan belum berjalan efektif. Kondisi tersebut antara lain ditunjukan adanya beberapa bidang yang belum memenuhi jumlah kebutuhan karyawan sehingga menyebabkan adanya rangkap jabatan pada beberapa karyawan.

Masalah selanjutnya yang dapat ditemukan yakni berkaitan dengan efektivitas dari fungsi pelatihan dan pengembangan, dan pemutusan hubungan kerja. Penelitian ini diharapkan dapat memberikan evaluasi kegiatan operasional perusahaan serta memberikan rekomendasi guna meningkatkan efektivitas perusahaan dalam mengelola SDM pada PT. Taspen (Persero) KCU Semarang. Tujuan dari penelitian ini adalah sebagai berikut:

1. Menganalisis pelaksanaan 8 (delapan) fungsi aktivitas pengendalian atau program SDM pada PT. Taspen (Persero) KCU Semarang.

2. Untuk menganalisis efektivitas 8 (delapan) fungsi aktivitas pengendalian atau program SDM pada PT. Taspen (Persero) KCU Semarang. 


\section{TINJAUAN PUSTAKA}

\section{Manajemen sumber daya manusia}

Pengertian Manajemen SDM menurut Hasibuan (2017) adalah ilmu dan seni yang mengatur hubungan dan peranan tenaga kerja agar efektif dan efisien membantu terwujudnya tujuan perusahaan, karyawan dan masyarakat. Menurut Dessler (2016) manajemen sumber daya manusia adalah proses untuk memperoleh, melatih, menilai, dan mengompensasi karyawan, dan untuk mengurus relasi tenaga kerja mereka, kesehatan dan keselamatan mereka, serta hal-hal yang berhubungan dengan keadilan. Fungsi manajemen SDM terdiri dari perencanaan, perorganisasian, pengarahan, pengendalian, pengadaan, pengembangan, kompensasi, kedisiplinan, pengintegrasian, pemeliharaan, dan pemberhentian (Hasibuan, 2017).

\section{Audit Manajemen}

Menurut Hery (2019) Audit manajemen dilakukan untuk mereview sebagian atau seluruh kegiatan organisasi dalam rangka mengevaluasi apakah sumber daya yang tersedia telah digunakan secara efektif dan efisien. Hal ini tidak berbeda dengan pernyataan Agoes (2004) yang menyatakan bahwa audit manajemen merupakan kegiatan pemeriksaan kegiatan operasional perusahaan yang telah ditentukan manajemen dengan maksud mengetahui efektifitas, efisiensi dan keekonomian sebuah kegiatan dalam perusahaan.
Tujuan audit manajemen menurut Bayangkara (2017), menyatakan bahwa audit manajemen bertujuan untuk mengidentifikasi kegiatan, program, dan aktivitas yang masih memerlukan perbaikan sehingga dengan rekomendasi yang diberikan nantinya dapat dicapai perbaikan atas pengelolaan berbagai kegiatan, program, dan aktivitas tersebut. Audit dititik beratkan pada berbagai objek audit yang diperkiran dapat diperbaiki, sehingga dapat mencegah kemungkinan terjadinya kerugian. Ruang lingkup audit manajemen meliputi seluruh aspek kegiatan manajemen. Ruang lingkup ini dapat berupa seluruh kegiatan atau dapat juga hanya mencakup bagian tertentu dari program/aktivitas yang dilakukan. Periode audit juga bervariasi, bisa untuk jangka waktu satu minggu, beberapa bulan, satu tahun, bahkan untuk beberapa tahun, sesuai dengan tujuan yang ingin dicapai (Bayangkara, 2017).

Menurut Bayangkara (2017) yang menjadi sasaran audit adalah kegiatan, aktivitas, program dan bidang-bidang dalam perusahaan yang diketahui atau diidentifikasi masih memerlukan perbaikan atau peningkatan, baik dari segi ekonomisasi, efisiensi, dan efektivitas. Ada tiga elemen pokok dalam sasaran audit:

1. Kriteria (criteria)

2. Penyebab (causes)

3. Akibat (effect) 


\section{Audit Manajemen atas Fungsi Sumber Daya Manusia (SDM)}

Menurut Bayangkara (2017), audit sumber daya manusia merupakan penilaian dan analisis yang komprehensif terhadap program-program sumber daya manusia. Walaupun secara khusus audit dilakukan pada departemen SDM, tetapi tidak terbatas hanya pada aktivitas yang terjadi pada departemen ini. Audit termasuk studi terhadap fungsi manajemen SDM pada organisasi secara keseluruhan termasuk yang dilaksanakan oleh manajer dan para supervisor.

Menurut Bayangkara (2017) ada beberapa hal yang ingin dicapai melalui audit SDM yang merupakan tujuan dilakukannya audit tersebut, antara lain:

1. Menilai efektivitas dari fungsi SDM,

2. Menilai apakah program atau ktivitas SDM telah berjalan secara ekonomis, efektif, dan efisien,

3. Memastikan ketaatan berbagai program atau aktivitas SDM terhadap ketetentuan hukum, peraturan dan kebijakan yang berlaku di perusahaan,

4. Mengidentifikasi berbagai hal yang masih dapat ditingkatkan terhadap aktivitas SDM dalam menunjang kontribusinya terhadap perusahaan,

5. Merumuskan beberapa langkah perbaikan yang tepat untuk meningkatkan ekonomisasi, efisiensi, dan efektivitas berbagai program atau aktivitas SDM.
Sehingga dapat dikatakan bahawa tujuan audit manajemen adalah untuk meneliti dan menilai kinerja perusahaan dari sudut pandang peningkatan efisiensi, efektivitas dan produktivitas kerja, baik dalam arti perusahaan sebagai keseluruhan maupun dalam arti berbagai komponennya. Menurut Bayangkara (2017), ada tiga pendekatan utama dalam audit SDM yang umum digunakan, yaitu:

1. Menentukan ketaatan pada hukum dan berbagai peraturan yang berlaku

2. Mengukur kesesuaian program dengan tujuan organisasi

3. Menilai kinerja program.

Dalam pelaksanaan audit, masingmasing pendekatan ini tidak berdiri sendiri tetapi lebih kepada kombinasi ketiganya untuk mencapai hasil audit yang secara optimal dapat membantu manajemen dalam meningkatkan keunggulan bersaing perusahaan. Penekanan pada salah satu pendekatan dimungkinkan tergantung pada tujuan audit yang telah ditetapkan.

Bayangkara (2017) menyatakan bahwa secara umum ada 5 (lima) tahapan yang harus dilakukan dalam audit manajemen dan audit SDM mengacu pada tahapan ini dalam pelaksanaannya. Langkah (tahapan) tersebut meliputi:

1. Audit Pendahuluan.

Pada tahap ini, auditor menekankan auditnya pada pencarian informasi latar belakang dan gambaran umum terhadap program atau aktivitas SDM 
yang diaudit. Informasi yang diperoleh pada tahap ini akan mengantarkan auditor pada perumusan tujuan audit sementara. Tujuan audit merupakan suatu hipotesis yang memerlukan pembuktian untuk menjawab pertanyaan (kecurigaan) auditor. Untuk mendapatakan jawaban ini, auditor menerapkan prosedur audit yang telah ditetetapkan. Tujuan audit dalam audit SDM harus dirumuskan terlebih dahulu dan memerlukan suatu survei awal untuk memahami kondisi yang terjadi berkaitan dengan program atau aktivitas yang diaudit serta masih memerlukan perbaikan untuk mendukung keberhasilan dimasa depan. Ketepatan perumusan tujuan audit ini sangat menentukan keberhasilan audit mencapai tujuannya.

2. Review dan Pengujian Pengendalian. Manajemen Sistem pengendalian manajemen yang dimiliki perusahaan menjadi pedoman yang digunakan oleh para manajer dan supervisor dalam mengendalikan proses yang berjalan agar tidak keluar dari ketentuan yang telah ditetapkan. Sistem pengendalian juga mengendalikan proses agar berjalan secara ekonomis, efisien dan efektif dalam mencapai tujuan perusahaan. Dalam audit SDM, auditor harus memahami hal ini terutama yang berkaitan dengan pengelolaan SDM.
Berdasarkan hasil review sistem pengendalian manajemen ini, auditor akan mampu lebih dalam memahami kondisi yang terjadi, sehingga dapat ditingkatkan menjadi tujuan audit yang sesungguhnya (karena cukup bukti yang mendukung permasalahan yang disoroti auditor yang tertuang dalam tujuan audit sementara), atau diabaikan karena terjadi sebaliknya. Di samping itu, berdasarkan hasil review ini auditor dapat mengambil keputusan apakah audit dapat dilanjutkan atau tidak mengingat ketersediaan data yang dibutuhkan dan kebebasan dalam melakukan audit (tidak menghadapi keterbatasan akses dalam melakukan audit).

3. Audit Lanjutan atau Terinci.

Dari temuan audit yang diperoleh, auditor meringkas dan melakukan pengelompokkan terhadap temuan tersebut ke dalam kelompok kondisi, kriteria, penyebab, dan akibat. Kondisi merupakan kenyataan riil yang ditemukan auditor berkaitan dengan program-program SDM yang ditetapkan perusahaan. Kriteria merupakan berbagai aturan, norma, dan standar sebagai pedoman bertindak bagi seluruh pihak berwenang dalam pengelolaan SDM. Penyebab adalah tindakan riil dari pihak-pihak yang berwenang dalam menangani SDM yang menyebabkan 
terjadinya kondisi yang ditemukan auditor, sedangkan akibat adalah temuan berupa akibat yang harus ditanggung perusahaan karena terjadinya perbedaan tindakan riil dengan kriteria yang telah ditetapkan.

Berbagai kelompok temuan tersebut kemudian dianalisis untuk memahami apakah permasalahan yang terjadi merupakan permasalahan yang berdiri sendiri atau saling terkait dengan permasalahan- permasalahan yang lain. Berkaitan dengan hal ini auditor harus mengembangkan temuan secara cermat sehingga dapat diketahui adanya penyimpangan yang terjadi, apa penyebab dari penyimpangan tersebut, apa akibat yang harus ditanggung perusahaan berkaitan dengan terjadinya penyimpangan tersebut. Dari berbagai kekurangan yang ditemukan kemudian auditor menyusun suatu rekomendasi untuk memperbaiki penyimpangan yang terjadi agar tidak terulang lagi di masa yang akan datang.

4. Pelaporan

Laporan harus disajikan dalam bahasa yang mudah dipahami. Laporan audit harus memuat tentang informasi latar belakang, kesimpulan audit dan disertai dengan temuan-temuan audit sebagai bukti pendukung kesimpulan tersebut. Laporan juga harus disajikan rekomendasi yang diusulkan auditor sebagai alternatif perbaikan terhadap penyimpangan (kekurangan) yang masih terjadi. Sebagai kelengkapannya laporan juga harus menyatakan ruang lingkup dari audit yang dilakukan.

5. Tindak Lanjut

Tindak lanjut merupakan implementasi dari rekomendasi yang diajukan auditor. Manajemen dan auditor harus sepakat dan secara bersama-sama dalam melaksanakan tindak lanjut perbaikan tersebut. Pada dasarnya keputusan untuk melakukan tindak lanjut sepenuhnya ada pada manajemen, tetapi dalam pelaksanaannya, auditor mendampingi agar tindak lanjut tersebut berjalan sesuai dengan rekomendasi yang diajukan dan dapat mencapai tujuannya.

\section{Penelitian terdahulu}

Maharani et al., 2014 dengan menggunakan 5 (lima) fungsi menyatakan bahwa tujuan audit manajemen sumber daya manusia adalah: perencanaan tenaga kerja, rekrutmen, seleksi, orientasi dan penempatan, pelatihan dan pengembangan. Tujuannya untuk menguji pengaruh persepsi karyawan atas audit sumber daya manusia terhadap kinerja karyawan The Haven Hotel Seminyak. Hasil penelitian menunjukkan bahwa perencanaan tenaga kerja, rekrutmen dan seleksi berpengaruh positif terhadap 
kinerja pegawai, sedangkan orientasi dan penempatan, serta pelatihan dan pengembangan tidak berpengaruh terhadap kinerja pegawai.

Minar dan Aditya (2019) dalam penelitian yang dilakukan pada Bank BNI Syariah juga menggunakan 5 (lima) fungsi dengan penekanan tambahan pada aspek spiritual menyatakan bahwa 22,1\% Audit Manajemen Sumber Daya Manusia berkontribusi terhadap kinerja karyawan. Audit Manajemen Sumber Daya Manusia dapat dijadikan sebagai salah satu acuan perusahaan dalam menilai kebijakannya terkait dengan manajemen karyawan terhadap kelangsungan operasi perusahaan.

Berangkat dari kedua model penelitian tersebut, penelitian ini akan menggunakan 8 (delapan) fungsi, diantaranya fungsi orientasi dan penempatan, pelatihan dan pengembangan, penilaian kinerja, pengembangan karir, sistem imbalan dan kompensasi, perlindungan karyawan, hubungan ketenagakerjaan, dan pemutusan hubungan kerja. Dimana delapan fungsi tersebut mengacu pada Bayangkara (2017).

\section{METODOLOGI PENELITIAN}

Penelitian ini merupakan penelitian deskriptif kualitatif dengan pendekatan komparatif, yaitu penelitan audit manajemen atas fungsi sumber daya manusia pada PT. Taspen (Persero) KCU
Semarang. Menurut Sugiyono (2018), Penelitian deskriptif adalah suatu penelitian yang dilakukan untuk mengetahui keberadaan variabel mandiri, baik hanya pada satu variabel atau lebih (variabel yang berdiri sendiri) tanpa membuat perbandingan dan mencari hubungan variabel itu dengan variabel yang lain. Metode yang digunakan dalam penelitian ini adalah metode kualitatif, yaitu metode penelitian ilmiah yang digunakan untuk meneliti pada kondisi obyek yang alamiah, di mana peneliti adalah sebagai instrumen kunci, teknik pengumpulan data dilakukan secara trianggulasi (gabungan observasi, wawancara, dokumentasi) (Sugiyono, 2020).

Penelitian deskriptif kualitatif ini menggunakan pendekatan komparatif yang berarti penelitian ini membandingkan keadaan satu variable atau lebih pada dua atau lebih sampel yang berbeda (Sugiyono, 2018). Penelitian ini akan membandingkan fungsi sumber daya manusia menurut peraturan yang dibuat dengan penerapan dalam kegiatan perusahaan. Penelitian ini dilakukan di PT. Taspen (Persero) KCU Semarang pada tahun 2020. Data yang digunakan pada penelitian ini adalah data kualitatif yang berkaitan dengan sejarah, visi-misi, struktur organisasi, job description serta catatan dan dokumen yang berhubungan dengan aktivitas sumber daya manusia (SDM) di PT. Taspen 
(Persero) KCU Semarang. Populasi dalam penelitian ini adalah seluruh karyawan pada PT. Taspen (Persero) KCU Semarang yang berjumlah 49 orang.

Indikator yang digunakan pada penelitian ini berdasarkan hasil observasi dan studi pustaka pada peraturan perusahaan yang berhubungan dengan aktivitas Sumber Daya Manusia di PT. Taspen (Persero) KCU Semarang. Indikator yang digunakan bertujuan untuk memastikan apakah aktivitas evaluasi SDM telah berjalan efektif dan memberikan rekomendasi perbaikan atas kekurangan ditemukan selama proses audit (Tabel 1).

Tabel 1

Fungsi SDM dan Indikator Penelitian

\begin{tabular}{|c|c|c|}
\hline No & Fungsi SDM & $\begin{array}{l}\text { Indikator } \\
\end{array}$ \\
\hline \multirow[t]{2}{*}{1} & Orientasi dan & 1. Pedoman orientasi dan penempatan \\
\hline & Penempatan & 2. Pelaksanaan orientasi dan penempataan \\
\hline \multirow[t]{4}{*}{2.} & Pelatihan dan & 1. Pedoman pelatihan dan pengembangan \\
\hline & Pengembangan & 2. Pelatihan dan pengembangan yang sesuai dengan kebutuhan \\
\hline & & 3. Metode pelatihan dan pengembangan \\
\hline & & 4. Pelaksanaan pelatihan dan pengembangan \\
\hline \multirow[t]{4}{*}{3.} & Penilaian Kinerja & 1. Pedoman penilaian kinerja \\
\hline & & 2. Tujuan penilaian kinerja \\
\hline & & 3. Pelaksanaan penilaian kinerja \\
\hline & & 4. Komunikasi hasil penilaian kinerja kepada karyawan \\
\hline \multirow[t]{4}{*}{4.} & Pengembangan Karier & 1. Pedoman pengembangan karier \\
\hline & & 2. Program pengembangan karier \\
\hline & & 3. Pelaksanaan program \\
\hline & & 4. Pengembagan karier \\
\hline \multirow[t]{2}{*}{5.} & Sistem Imbalan dan & 1. Pedoman pemberian imbalan dan kompensasi \\
\hline & Kompensasi & 2. Pelaksanaan imbalan dan kompensasi \\
\hline \multirow[t]{4}{*}{6.} & Perlindungan & 1. Pedoman perlindungan karyawan \\
\hline & Karyawan & 2. Pedoman sistem komunikasi bahaya kerja \\
\hline & & 3. Pelatihan P3K terhadap karyawan \\
\hline & & 4. Pelaksanaan perlindungan terhadap karyawan \\
\hline \multirow[t]{2}{*}{7.} & Hubungan & 1. Pedoman hubungan ketenagakerjaan \\
\hline & Ketenagakerjaan & 2. Pelaksanaan hubungan ketenagakerjaan \\
\hline \multirow[t]{3}{*}{8.} & Pemutusan Hubungan & 1. Pedoman PHK \\
\hline & Kerja $(\mathrm{PHK})$ & 2. Pemahaman karyawan atas timbulnya PHK \\
\hline & & 3. Pemrosesan PHK \\
\hline
\end{tabular}

Sumber : Bayangkara, 2007

Teknik pengumpulan data merupakan suatu cara yang digunakan oleh peneliti dalam memperoleh data penelitian (Jaya, 2020). Teknik pengumpulan data yang digunakan dalam penelitian ini adalah Wawancara, kuesioner dan dokumentasi.
Tahap-tahap analisis data dalam penelitian ini adalah sebagai berikut:

1. Audit Pendahuluan.

Pada tahap ini lebih ditekankan untuk memperoleh informasi umum dari PT. Taspen (Persero) KCU Semarang seperti 
visi-misi, sejarah, struktur organisasi, tupoksi, dan program serta data yang berhubungan dengan fungsi SDM sehingga diperoleh pemahaman menyeluruh atau gambaran yang memadai pada semua aspek penting dari perusahaan yang berkaitan dengan audit manajemen yang dilakukan. Ruang lingkup audit manajemen atas delapan fungsi SDM, yaitu (1) orientasi dan penempatan, (2) pelatihan dan pengembangan, (3) penilaian kinerja, (4) pengembangan karier, (5) sistem imbalan dan kompensasi, perlindungan karyawan, (7) hubungan ketenagakerjaan serta (8) pemutusan hubungan kerja

2. Review dan Pengujian Pengendalian Manajemen.

Review dan pengujian terhadap pengendalian manajemen obyek audit dengan tujuan untuk menilai efektivitas pengendalian manajemen dalam mendukung pencapain tujuan dan keseluruhan PT. Taspen (Persero) KCU Semarang, termasuk perencanaan, kebijakan dan prosedur yang ditetapkan serta praktek-praktek yang dijalankan dalam pengelolaan kegiatan-kegiatan pada perusahaan. Penilaian terhadap pengendalian manajemen atas fungsi SDM pada PT. Taspen (Persero) KCU Semarang menggunakan kuesioner dengan pertanyaan-pertanyaan yang berkaitan dengan ruang lingkup audit, yaitu proses orientasi dan penempatan, pelatihan dan pengembangan, penilaian kinerja, pengembangan karir, sistem imbalan dan kompensasi, perlindungan karyawan, hubungan ketenagakerjaan serta pemutusan hubungan kerja.

3. Audit Terinci

Pada tahap ini, bukti-bukti yang diperoleh selama melaksanakan audit dikumpulkan. Data yang diperoleh kemudian digolongkan kedalam unsur temuan audit yaitu kondisi, kriteria, penyebab, dan akibat. Informasi yang diperoleh dari data-data tersebut dianalisis untuk memahami permasalahan yang terjadi sehingga diperoleh suatu kesimpulan audit, dan kemudian menyusun suatu rekomendasi atas kelemahankelemahan yang ditemukan

4. Pelaporan

Tahap ini bertujuan untuk mengkomunikasikan hasil audit termasuk rekomendasi berdasarkan evaluasi dan penilaian terhadap pengelolaan fungsi SDM pada PT. Taspen (Persero) KCU Semarang. Laporan atas temuan audit yang terdiri atas informasi latar belakang, kesimpulan audit, rekomendasi dan ruang lingkup audit 


\section{HASIL DAN PEMBAHASAN}

Setelah dilakukan audit sumber daya manusia pada PT. Taspen (Persero) KCU Semarang, dapat diketahui bahwa aktivitas fungsi sumber daya manusia yang telah berjalan diperusahaan ini sebagai berikut:

1. Orientasi dan Penempatan

Orientasi bagi setiap karyawan baru harus dilaksanakan untuk menyatakan bahwa mereka betul-betul diterima dengan tangan terbuka menjadi karyawan yang akan bekerja sama dengan karyawan lain diperusahaan. Sedangkan penempatan bertujuan untuk menempatkan orang yang tepat pada posisi (jabatan) yang tepat sesuai dengan peraturan yang berlaku. PT. Taspen (Persero) KCU Semarang sudah memiliki kebijakan orientasi dan penempatan yang jelas dan tertulis. Orientasi dan penempatan pada PT. Taspen (Persero) KCU Semarang belum berjalan efektif karena terdapat kondisi atau pelaksanaan dari program penempatan yang tidak sesuai dengan kebijakan yang telah ditetapkan oleh perusahaan. Hal tersebut tercermin pada pelaksanaan rotasi karyawan yang tidak sesuai dengan peraturan yaitu belum dilakukannya rotasi/ mutasi terhadap pegawai yang sudah menduduki 3 (tiga) tahun pada bidang yang sama. Kondisi tersebut menimbulkan kejenuhan karyawan karena tidak ada penyegaran dalam pekerjaan baru. Kemudian rotasi dilakukan antar karyawan dengan bidang kerja yang berbeda. Kondisi tersebut mengakibatkan penempatan karyawan yang tidak sesuai dengan kemampuan atau keahlian yang dimilikinya. Selanjutnya terdapat beberapa bidang kerja yang belum memenuhi jumlah karyawan yang menimbulkan rangkap jabatan dan beban kerja yang berlebih. Dari kondisi di atas dapat dikatakan bahwa orientasi dan penempatan di PT. Taspen (Persero) KCU Semarang belum berjalan efektif.

2. Pelatihan dan Pengembangan

Pelatihan menekankan pada peningkatan keterampilan dan kemampuan SDM dalam melaksanakan tugas dan tanggung jawabnya saat ini, sedangkan pengembangan SDM lebih menekankan pada peningkatan kinerja SDM di masa yang akan datang. Pelatihan daan pengembangan SDM bertujuan untuk meningkatkan ketrampilan dan kemampuan SDM dalam mengemban tugas dan tanggungjawabnya baik saat ini maupun di masa yang akan datang. Pusat perhatian dalam pelatihan dan pengembangan SDM adalah bagaimana manjadikan karyawan memahami dan mampu melaksanakan strategi yang telah ditetapkan perusahaan dalam mencapai tujuannya. 
Pelatihan dan Pengembangan di PT. Taspen (Persero) KCU Semarang tidak diikuti secara khusus oleh karyawan yang membutuhkan pelatihan, yang diikuti semua karyawan. Pelatihan yang ada seharusnya berasal dari kantor pusat dan kantor cabang (KCU semarang) tetapi kantor cabang tidak melakukan pelatihan sesuai dengan peraturan yang ada. Peserta pelatihan ditetapkan langsung oleh kantor pusat. Dari kondisi diatas dapat dikatakan bahwa pelatihan dan pengembangan di PT. Taspen (Persero) KCU Semarang belum berjalan secara efektif.

3. Penilaian Kinerja

Penilaian kinerja bermanfaat untuk mengevaluasi kerja karyawan dan untuk mengembangkan kemampuan serta memotivasi karyawan, atau dengan kata lain penilaian kinerja karyawan dapat mengukur kinerja karyawan tersebut. Penilaian kinerja dilakukan dengan menghubungkan kinerja karyawan dalam melaksanakan tugas dan tanggung jawabnya dengan standar (ukuran) keberhasilan yang telah ditetapkan sebelumnya untuk tugas dan tanggung jawab tersebut. Hasil penilaian kerja karyawana dapat mencerminkan sebagian dari kinerja perusahaan. Penilaian kinerja pada PT. Taspen (Persero) KCU Semarang sudah berjalan efektif. Penilaian kinerja yang dilakukan perusahaan telah berjalan dengan baik sesuai dengan prosedur dan kebijakan yang berlaku. Perusahaan melakukan penilaian kinerja tiap 6 bulan sekali. Evaluasi karyawan dilaksanakan secara berkala setahun sekali. Hasil penilaian dan evaluasi terdokumentasi dengan baik dan disampaikan kepada karyawan sebagai umpan balik.

4. Pengembangan Karir

Pengembangan karir seorang karyawan dapat menunjukkan semakin meningkatnya kemampuan karyawan dalam memegang tugas, wewenang, dan tanggungjawab yang lebih besar dalam pekerjaan. Program perencanaan dan pengembangan karier memungkinkan karyawan mengalami kenaikan pangkat atau jabatan sesuai syarat dan kemampuan. Karyawan harus memiliki kemampuan yang baik dan memadai dalam ketrampilan serta keahlian yang sifatnya teknis maupun manajerial sebagai seorang pengambil keputusan. Pengembangan karir pada PT. Taspen (Persero) KCU Semarang sudah berjalan efektif. Karyawan yang memenuhi persyaratan akan diajukan untuk menjalani assessment test dan fit and proper test, karyawan yang mendapat nilai lebih dari 75 (tujuh puluh lima) dapat dipromosikan untuk jabatan dan golongan yang lebih tinggi. Program tersebut berlaku sama untuk seluruh 
karyawan. Hal ini menciptakan motivasi pegawai dalam bekerja maksimal.

5. Sistem Imbalan dan Kompensasi

Kompensasi dan balas jasa diberikan kepada seorang karyawan karena telah memberikan tenaga maupun pikiran untuk kemajuan perusahaan. Kompensasi merupakan masalah yang cukup sensitif bagi karyawan, karena kompensasi menjadi pendorong seseorang untuk bekerja, dan berpengaruh terhadap moral serta disiplin kerja karyawan. Perusahaan seharusnya dapat memberikan kompensasi secara seimbang dengan beban kerja yang dipikul karyawan. Tujuan manajemen kompensasi adalah untuk membantu perusahaan mencapai tujuannya dan menjamin terciptanya keadilan internal dan eksternal. Sistem imbalan dan kompensasi pada PT. Taspen (Persero) KCU Semarang sudah berjalan efektif. Struktur dan kebijakan kompensasi yang diberikan kepada karyawan sudah sesuai dengan peraturan pemerintah serta kompensasi memberikan kepuasan kepada karyawan.

6. Perlindungan Karyawan

Perlindungan karyawan yang mencakup kebijakan keselamatan dan kesehatan kerja menunjukkan kondisi fisiologi (fisik) dan psikologis karyawan yang diakibatkan oleh lingkungan dan fasilitas kerja yang disediakan perusahaan. Jika perusahaan melaksanakan tindakan keselamatan dan kesehatan yang efektif, maka akan mencegah atau mengurangi pekerja yang menderita cedera atau penyakit jangka pendek maupun jangka panjang sebagai akibat dari pekerjaan mereka di perusahaan tersebut. Perlindungan karyawan pada PT. Taspen (Persero) KCU Semarang sudah berjalan secara efektif. Karyawan mendapatkan pelatihan Pertolongan Pertama Pada Kecelakaan (P3K) yang memadai dari Dinas Kesehatan Kota Semarang dan Dinas Pemadam Kebakaran Kota Semarang. PT. Taspen (Persero) KCU Semarang menyediakan tempat kerja yang aman dan sehat bagi karyawan dan memberikan perlindungan yang memadai berupa asuransi.

7. Hubungan Ketenagakerjaan

Hubungan kerja merupakan hubungan kerja sama antara semua pihak yang berada dalam proses operasional di suatu perusahaan. Pemeliharaan hubungan pekerja dalam rangka keseluruhan proses manajemen SDM berkisar pada pemikiran bahwa hubungan yang serasi dan harmonis antara manajemen dengan karyawan yang terdapat dalam perusahaan mutlak perlu ditumbuhkan, dijaga, dan dipelihara demi kepentingannya dalam perusahaan.

Hubungan ketenagakerjaan di PT. Taspen (Persero) 
KCU Semarang sudah berjalan efektif. Hal ini dibuktikan hubungan karyawan bagian lain dengan SDM berjalan dengan baik, kemudian hubungan karyawan dengan sesame rekan kerja maupun atasan terjalin dengan baik.

8. Pemutusan Hubungan Kerja (PHK)

Pemutusan hubungan kerja adalah pemberhentian pegawai, baik untuk sementara maupun selamanya yang dilakukan oleh perusahaan atas permintaan pegawai atau karena kehendak pihak perusahaan. Empat macam bentuk pemutusan hubungan kerja, yaitu pensiun, pemberhentian atas permintaan sendiri, pemberhentian langsung oleh pihak perusahaan dan pemberhentian sementara. Pemutusan hubungan kerja di PT. Taspen (Persero)
KCU Semarang belum berjalan efektif. Perusahaan yang sudah memiliki peraturan PHK yang jelas dan di dokumentasikan dengan baik tetapi tidak seluruh karyawan mengetahui dengan baik tentang peraturan PHK yang dimiliki oleh perusahaan. Perusahaan diperbolehkan melakukan PHK dikarenakan beberapa hal. Hal ini dilakukan demi menjaga stabilitas kerja perusahaan.

Hasil pembahasan diatas telah memberikan penjelasan tentang 8 (delapan) fungsi SDM yang ada di PT. Taspen (Persero) KCU Semarang. Pembahasan telah dilakukan secara rinci pada setiap fungsi SDM yang terdapat pada perusahaan. Rangkuman dari pembahasan 8 fungsi tersebut dapat dilihat pada tabel 2 .

Tabel 2

Rangkuman Hasil Pembahasan

\begin{tabular}{|c|c|c|c|c|c|}
\hline \multirow{3}{*}{ No } & \multirow{3}{*}{ Fungsi } & \multirow{2}{*}{\multicolumn{2}{|c|}{$\begin{array}{l}\text { Pelaksanaan } \\
\text { Fungsi SDM }\end{array}$}} & \multicolumn{2}{|c|}{ Efektivitas } \\
\hline & & & & Fun & SDM \\
\hline & & Sudah & Belum & Sudah & Belum \\
\hline 1 & Orientasi Dan Penempatan & $\sqrt{ }$ & & & $\sqrt{ }$ \\
\hline 2 & Pelatihan dan Pengembang an & $\sqrt{ }$ & & & $\sqrt{ }$ \\
\hline 3 & Penilaian Kinerja & $\sqrt{ }$ & & $\sqrt{ }$ & \\
\hline 4 & Pengembangan Karier & $\sqrt{ }$ & & $\sqrt{ }$ & \\
\hline 5 & Sistem Imbalan dan Kompensasi & $\sqrt{ }$ & & $\sqrt{ }$ & \\
\hline 6 & Perlindungan Karyawan & $\sqrt{ }$ & & $\sqrt{ }$ & \\
\hline 7 & Hubungan Ketenagakerjaan & $\sqrt{ }$ & & $\sqrt{ }$ & \\
\hline 8 & Pemutusan Hubungan Kerja & $\sqrt{ }$ & & & $\sqrt{ }$ \\
\hline
\end{tabular}

\section{KESIMPULAN}

1. PT. Taspen (Persero) KCU Semarang telah melaksanakan 8 (delapan) fungsi SDM, yaitu orientasi dan penempatan, pelatihan dan pengembangan, penilaian kinerja, pengembangan karier, sistem imbalan dan kompensasi, perlindungan karyawan, hubungan ketenagakerjaan serta pemutusan hubungan kerja. 
2. Dari 8 (delapan) fungsi SDM pada PT. Taspen (Persero) KCU Semarang di dapatkan hasil bahwa terdapat 5 (lima) fungsi SDM yang sudah efektif dan 3 (tiga) fungsi SDM yang belum efektif. Fungsi SDM yang sudah efektif ada 5 (lima), yaitu penilaian kinerja, pengembangan karier, sistem imbalan dan kompensasi, perlindungan karyawan hubungan ketenagakerjaan, serta fungsi SDM yang belum dilaksanakan secara efektif ada 3 (tiga) fungsi yaitu orientasi dan penempatan, pelatihan dan pengembangan, dan pemutusan hubungan kerja.

\section{IMPLIKASI PENELITIAN}

Implikasi dalam penelitian bagi PT.Taspen (Persero) KCU Semarang dapat digunakan sebagai bahan pertimbangan dan evaluasi mengenai tiga fungsi SDM yang belum dilaksanakan secara efektif, sehingga dapat digunakan untuk pengambilan keputusan untuk memperbaiki kinerja manajemen SDM khususnya pada bagian umum.

\section{ACKNOWLEDGEMENT}

Peneliti mengucapkan terima kasih kepada pimpinan dan karyawan bagian umum PT.Taspen (Persero) KCU Semarang yang telah membantu dalam memberikan data maupun informasi untuk penelitian ini.

\section{DAFTAR PUSTAKA}

Anawati, Lusi dan Sutjipto Ngumar. 2016. "Audit Manajemen Untuk Mengevaluasi Efektivitas Dan Efisiensi Rekrutmen Sumber Daya Manusia”. Jurnal Ilmu dan Riset Akuntansi: Volume 5, Nomor 1, Januari 2016. ISSN: 2460-0585.

Bayangkara, IBK. 2017. Audit Manajemen Prosedur dan Implementasi. Jakarta: Salemba Empat.

Dessler, Gary. 2016. Manajemen Sumber Daya Manusia. Terjemahan Diana Angelica. Jakarta: Salemba Empat.

Hakim, Abdul. 2014. Dinamika Sumber Daya Manusia Dalam Organisasi. Semarang: EF Press Digimedia.

Hasibuan, Malayu P. 2017. Manajemen Sumber Daya Manusia. Jakarta: PT Bumi Aksara

Hery. 2019. Auditing: Dasar-Dasar Pemeriksaan Akuntansi. Jakarta: PT. Grasindo

Jaya, I Made. 2020. Metode Penelitian Kuantitatiffan Kualitatif. Jakarta: Quadrant

Minar, Demsi and Aditya, Reza. 2019. AUDIT Manajemen Sumber Daya Manusia (Studi Kasus Pada Pt. Bank BNI Syariah Kantor Cabang Tasikmalaya). Jurnal Techno Socio Ekonomika Universitas Sangga Buana YPKP, 12 (1). pp. 1-10. ISSN 1979-4835.

Nur, Faujiah dan Lukman Hakim Siregar. 2019. "Audit Manajemen Pada Kantor Kesyahbandar Utama Belawan". Jurnal Bisnis Corporate: Vol. 4 No. 1, Juni 2019. ISSN: $2579-6445$ 
Putri Maharani, Luh Gede Dea; Ratna Sari, Maria M. 2014. Persepsi Karyawan Atas Audit Manajemen Sumber Daya Manusia Pada Kinerja Karyawan. E-Jurnal Akuntansi, [S.1.], v. 8, n. 3, p. 538-553, sep. 2014. ISSN 2302-8556. Available at:

https://ocs.unud.ac.id/index.php/Akuntansi/article/view/8377 Date accessed: 29 apr. 2021.

Rosuliana, Tita. et al. 2017. "Audit Manajemen Atas Fungsi Sumber Daya Manusia Untuk Meningkatkan Kinerja Pada Perusahaan PT. PLN (Persero) P2B Apb Jawa Timur”. Jurnal Ekonomi Akuntansi Vol. 3. Issue. 3.

Sugiyono. 2018. Metode Penelitian Pendidikan Pendekatan Kuantitatif, Kualitatif, dan R\&D. Bandung: Alfabeta

Sugiyono. 2020. Metode Penelitian Kualitatif. Bandung: Alfabeta 